\title{
Effect of nanoencapsulation on the phenomenon of drug interaction between anti-M.avium drug, rifabutin and anti-HIV drug, ritonavir by employing poly (lactide-co-glycolide) nanoparticles
}

\author{
Tapinder Grewal", Sadhna Sharma \\ From First International Science Symposium on HIV and Infectious Diseases (HIV SCIENCE 2012) \\ Chennai, India. 20-22 January 2012
}

\section{Background}

Interaction between M.avium and HIV drugs is unavoidable in HIV patients as for an improved life expectancy of HIV patients, additional medications have to be administered along with HIV drugs. The anti-M.avium drug rifabutin and protease inhibitor, ritonavir are associated with significant drug interactions involving the cytochrome P450 (CYP) enzyme system. Little information is available on the role of various drug delivery strategies in alleviations of interactions between anti- $M$. avium and anti-HIV drugs. The purpose of the present study was to evaluate effect of encapsulation of rifabutin and ritonavir in PLGA nanoparticles on the already known drug interaction exhibited by these drugs.

\section{Methods}

This study was designed including administration of rifabutin and ritonavir singly and in combination in free and nanoencapsulated form to swiss albino mice. Blood samples were taken following drug administration at various time intervals and pharmacokinetic parameters were assessed as: area under plasma drug concentration

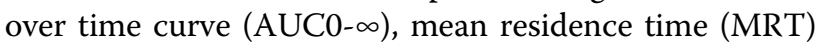
and Cmax etc.

\section{Results}

Overall, nanoencapsulation was observed to avoid the known adverse drug interactions between RBT and RTV in the drug interaction study. (p-value $<0.001$ ).

\footnotetext{
* Correspondence: peace7grewal@yahoo.in

Department of Biochemistry, Postgraduate Institute of Medical Education and Research, Chandigarh, India
}

(c) 2012 Grewal and Sharma; licensee BioMed Central Ltd. This is an Open Access article distributed under the terms of the Creative Commons Attribution License (http://creativecommons.org/licenses/by/2.0), which permits unrestricted use, distribution, and reproduction in any medium, provided the original work is properly cited.

\section{and take full advantage of:}

- Convenient online submission

- Thorough peer review

- No space constraints or color figure charges

- Immediate publication on acceptance

- Inclusion in PubMed, CAS, Scopus and Google Scholar

- Research which is freely available for redistribution

Submit your manuscript at

C Biomed Central 